ORIGINAL ARTICLE

\section{Effect of Aspirin or Resistant Starch on Colorectal Neoplasia in the Lynch Syndrome}

\author{
John Burn, M.D., D. Timothy Bishop, Ph.D., Jukka-Pekka Mecklin, M.D., \\ Finlay Macrae, M.D., Gabriela Möslein, M.D., Sylviane Olschwang, Ph.D., \\ Marie-Luise Bisgaard, M.D., Raj Ramesar, Ph.D., Diana Eccles, M.D., \\ Eamonn R. Maher, M.D., Lucio Bertario, M.D., Heikki J. Jarvinen, M.D., \\ Annika Lindblom, M.D., D. Gareth Evans, M.D., Jan Lubinski, M.D., \\ Patrick J. Morrison, M.D., Judy W.C. Ho, M.D., Hans F.A. Vasen, M.D., \\ Lucy Side, M.D., Huw J.W. Thomas, M.D., Rodney J. Scott, Ph.D., \\ Malcolm Dunlop, M.D., Gail Barker, B.A., Faye Elliott, M.Sc., Jeremy R. Jass, M.D., \\ Ricardo Fodde, Ph.D., Henry T. Lynch, M.D., and John C. Mathers, Ph.D., \\ for the CAPP2 Investigators*
}

\section{A BSTRACT}

\section{BACKGROUND}

Observational and epidemiologic data indicate that the use of aspirin reduces the risk of colorectal neoplasia; however, the effects of aspirin in the Lynch syndrome (hereditary nonpolyposis colon cancer) are not known. Resistant starch has been associated with an antineoplastic effect on the colon.

\section{METHODS}

In a randomized, placebo-controlled trial, we used a two-by-two design to investigate the effects of aspirin, at a dose of $600 \mathrm{mg}$ per day, and resistant starch (Novelose), at a dose of $30 \mathrm{~g}$ per day, in reducing the risk of adenoma and carcinoma among persons with the Lynch syndrome.

\section{RESULTS}

Among 1071 persons in 43 centers, 62 were ineligible to participate in the study, 72 did not enter the study, and 191 withdrew from the study. These three categories were equally distributed across the study groups. Over a mean period of 29 months (range, 7 to 74), colonic adenoma or carcinoma developed in 141 participants. Of 693 participants randomly assigned to receive aspirin or placebo, neoplasia developed in 66 participants receiving aspirin (18.9\%), as compared with 65 receiving placebo (19.0\%) (relative risk, $1.0 ; 95 \%$ confidence interval [CI], 0.7 to 1.4$)$. There were no significant differences between the two groups with respect to the development of advanced neoplasia (7.4\% and 9.9\%, respectively; $\mathrm{P}=0.33$ ). Among the 727 participants receiving resistant starch or placebo, neoplasia developed in 67 participants receiving starch (18.7\%), as compared with 68 receiving placebo (18.4\%) (relative risk, $1.0 ; 95 \%$ CI, 0.7 to 1.4). Advanced adenomas and colorectal cancers were evenly distributed in the two groups. The prevalence of serious adverse events was low, and the events were evenly distributed.

\section{CONCLUSIONS}

The use of aspirin, resistant starch, or both for up to 4 years has no effect on the incidence of colorectal adenoma or carcinoma among carriers of the Lynch syndrome. (Current Controlled Trials number, ISRCTN59521990.)

\begin{tabular}{l}
\hline A correction has been \\
published: N Engl J Med \\
2009;360(14):1470. \\
http://content.nejm.org/cgi/ \\
content/full/360/14/1470 \\
This has been attached at the \\
end of the PDF.
\end{tabular}

The affiliations of the authors are listed in the Appendix. Address reprint requests to Dr. Burn at the Institute of Human Genetics, Newcastle University, International Centre for Life, Central Pkwy., Newcastle upon Tyne NEl 3BZ, United Kingdom, or atjohn.burn@ncl.ac.uk.

*Investigators participating in the Colorectal Adenoma/carcinoma Prevention Programme 2 (CAPP2) are listed in the Appendix.

N EnglJ Med 2008;359:2567-78

Copyright (๑) 2008 Massachusetts Medical Society. 
T HE REGULAR USE OF ASPIRIN OR ASPIrin-like agents is associated with a moderate reduction in the risk of colonic polyps and colorectal cancer. ${ }^{1-4}$ Randomized trials of high-fiber diets have not shown a reduction in the risk of adenomas or colorectal cancer, ${ }^{5}$ but none have investigated the effects of resistant starch. There is epidemiologic evidence of a negative correlation between colon cancer and starch intake. ${ }^{6}$ Resistant starches escape digestion in the upper gut; colonic fermentation yields short-chain fatty acids, including butyrate, which has antineoplastic properties. ${ }^{7}$ In carcinogen-treated rats, resistant starch reduces the development of intestinal tumors ${ }^{8,9}$ and the production of aberrant crypt foci, ${ }^{10}$ lowers mucosal DNA damage, ${ }^{11}$ and increases apoptosis of damaged cells. ${ }^{12}$ Conversely, excess numbers of polyps in the small bowel develop in strain Apc1638N mice fed a diet containing high amounts of resistant starch (200 g per kilogram). ${ }^{13}$

We conducted a trial of colorectal-cancer prevention that focused on carriers of DNA mismatch-repair gene defects. These abnormalities underlie the Lynch syndrome (hereditary nonpolyposis colon cancer), an autosomal dominant genetic defect that confers a predisposition to colorectal cancer. Up to $5 \%$ of colorectal cancers result from the Lynch syndrome, which is characterized by microsatellite instability of tumors. Several organs are susceptible to cancer, including the intestines, endometrium, and ovaries. ${ }^{14}$ The Lynch syndrome probably represents a "model system" for one of six sporadic cancers featuring microsatellite instability due to somatic MLH1 silencing. ${ }^{15}$ In patients with the Lynch syndrome, adenomas appear at a mean age of 42.5 years, and the first diagnosis of colorectal cancer occurs at a mean age of about 45 years. The risk of colon cancer among mutation carriers is $10 \%$ over a period of 10 years. In one study, colonic neoplasia had developed in $70.3 \%$ of carriers by 60 years of age. ${ }^{16}$

We describe a randomized trial of chemoprevention with the use of $600 \mathrm{mg}$ of aspirin, $30 \mathrm{~g}$ of resistant starch, or both daily for up to 4 years in patients with the Lynch syndrome.

\section{METHODS}

In this two-by-two factorial, randomized, doubleblind, placebo-controlled trial, we tested whether the use of enteric-coated aspirin at a dose of 600 mg per day, resistant starch at a dose of $30 \mathrm{~g}$ per day, or both prevents the development of colonic adenomas or colorectal cancer in patients with the Lynch syndrome. In this study, we used the collective term "neoplasia" to refer to colonic adenomas and colorectal cancer; although the term was used in the general sense of "new growth," it did not include presumably benign hyperplastic polyps. Initially, participants were enrolled for 2 years. In 2001, an approved protocol amendment allowed participants to be invited, immediately before the 2-year date, to continue in the trial for 2 more years.

The study was designed by members of the international steering committee of the Colorectal Adenoma/Carcinoma Prevention Programme 2 (CAPP2). The data were gathered and analyzed by the CAPP2 investigators. During the trial and before publication, except as noted below, data were kept confidential from the sponsors, institutions, and all study organizers except for two of the authors and the data and safety monitoring committee. Bayer and National Starch and Chemical provided the study agents free of charge, including the cost of packaging, and they made donations to Newcastle University to help cover the cost of administration and distribution. They had no influence on the study design, conduct, or analysis or on preparation of the manuscript. The contracts associated with their donations required that the sponsors be given the right to review the results before submission of the manuscript, with up to 90 days for evaluation.

All relevant research ethics committees approved the study. Approval included the addition of an undeclared inert starch-compliance biomarker, 4-aminobenzoic acid (in Denmark, the addition of this biomarker was revealed). All participants gave written informed consent for participation in the study, including explicit consent for the provision of blood and tissue samples.

\section{PATIENTS}

Eligible patients were older than 25 years of age and were proven carriers of a pathologic mismatch-repair mutation ("genetic diagnosis") or members of a family that met the Amsterdam diagnostic criteria and had a personal history of a cured Lynch syndrome neoplasm but an intact colon ("clinical diagnosis"). Colonoscopic exam- 
ination and clearance of polyps within 3 months after recruitment were prerequisites. Exclusion criteria were pregnancy, contraindications for the use of aspirin, the use of antiinflammatory agents, and severe intercurrent disease. Patients with recent bowel cancer were excluded for 1 year if the pathological findings were consistent with Dukes' stage A, for 2 years if they were consistent with Dukes' stage B, and for 5 years if they were consistent with Dukes' stage C or D. If a partial colectomy had been performed, a daily bowel movement of three or fewer formed stools was required.

\section{STUDY DESIGN}

The protocol specified a colonoscopic examination at study entry and an exit colonoscopic examination after 2 years of the study intervention, along with routine surveillance. Copies of histologic reports plus pathological samples were requested for independent pathological review.

Participants were randomly assigned separately for the two interventions (either assignment to aspirin or placebo or assignment to resistant starch or placebo), and half the participants were randomly assigned to receive either the active agent or placebo for each intervention. This randomization should have resulted in four groups of equal size for assignments to aspirin plus placebo, aspirin plus starch, starch plus placebo, and placebo plus placebo. For some persons, however, randomization to one intervention was precluded by a factor such as sensitivity to aspirin, and in such cases, randomization to the other intervention was permitted; this resulted in four additional (smaller) groups. For the main analysis, the two interventions were analyzed separately (e.g., participants who were randomly assigned to receive aspirin were compared with participants who were randomly assigned to receive aspirin plus placebo, regardless of whether they received resistant starch or placebo starch). Only the interaction analysis excluded participants who were randomly assigned to receive a single agent.

Randomization was computer-generated. The study centers were categorized into six geographic groups - Americas, southern Europe (the Iberian Peninsula and Italy), northern Europe, South Africa, the United Kingdom, and the Pacific Rim (Australia and Hong Kong). Block randomization (in blocks of 16) was performed separately for each group of centers to ensure balance across the four main study groups.

\section{STUDY REGIMENS}

The daily regimen consisted of $30 \mathrm{~g}$ of resistant starch (Novelose, National Starch and Chemical) or placebo cornstarch (with recommended administration in two separate doses) or two entericcoated aspirin tablets plus placebo or aspirin plus resistant starch. The test starch was a 1:1 blend of Novelose 240 and Novelose 330. Novelose 240, based on a corn (maize) hybrid containing $70 \%$ amylose and 30\% amylopectin, is a granular source of resistant starch; Novelose 330 is similar but nongranular. The estimated dose of resistant starch was $13.2 \mathrm{~g}$ (habitual intake in Europe was estimated to be $4.1 \mathrm{~g}$ per day ${ }^{17}$; a daily dose of $28 \mathrm{~g}$ of resistant starch was found by others to cause considerable bloating. The resistant-starch control was waxy starch (Amioca) containing only amylopectin, a highly branched high-molecular-weight polymer of $\alpha 1$,4-linked glucose with negligible resistant starch. The compliance biomarker used to assess compliance with the starch regimen was 4-aminobenzoic acid at a level of $50 \mathrm{mg}$ per day.

For aspirin, we used an enteric-coated tablet (Bayer) that contained $300 \mathrm{mg}$ of acetylsalicylic acid. The aspirin placebo contained $36 \mathrm{mg}$ of calcium hydrogen phosphate, a trivial dietary dose.

The investigators and patients were unaware of the study-group assignments. Dispensing and related records were managed by the Newcastle Hospitals NHS Foundation Trust Pharmacy. After colonoscopic examination at study entry, packs containing the study drugs were sent directly to the participants or local clinicians and thereafter were sent every 6 months, when compliance data were collected.

\section{STATISTICAL ANALYSIS}

Descriptive statistics were used for study variables (including age, sex, eligibility status, and months in the study), with frequency tabulations for categorical variables and summary statistics (mean and range) for continuously distributed variables.

Participants who underwent a follow-up colonoscopic examination were included in the analyses of treatment effects. The primary outcome was detection of at least one adenoma or colorectal carcinoma at follow-up; since intervals be- 
tween colonoscopic examinations and the duration of participation in the study varied, the analysis considered time in the study in its entirety. Secondary outcomes were the detection of an adenoma only, colorectal cancer only, adenoma and colorectal cancer, and advanced adenoma or colorectal cancer. A neoplasm was classified as an advanced adenoma on the basis of one or more of the following features: a diameter of $1 \mathrm{~cm}$ or more, a villous or tubulovillous component, or high-grade dysplasia. Other secondary outcomes were the neoplastic burden, defined as the sum of the maximum diameters of neoplasms detected by means of endoscopic examination during the study, and other cancers associated with the Lynch syndrome.

The primary analysis compared the occurrence of each outcome involving a neoplasm according to whether the subject received resistant starch or aspirin. Secondary analyses were ad-

\begin{tabular}{|c|c|c|c|c|}
\hline Variable & $\begin{array}{l}\text { Participants Recruited } \\
\text { and Given Study Drug } \\
\qquad(\mathrm{N}=937)\end{array}$ & $\begin{array}{l}\text { Participants Included } \\
\text { in Outcome Analysis } \\
\qquad(N=746)\end{array}$ & $\begin{array}{l}\text { Participants Not } \\
\text { Included in Outcome } \\
\text { Analysis }(\mathrm{N}=191)\end{array}$ & P Value* \\
\hline Age at study entry $-\mathrm{yr}$ & & & & 0.63 \\
\hline Mean & 45 & 46 & 46 & \\
\hline Range & $25-79$ & $25-79$ & $25-67$ & \\
\hline Sex - no. (\%) & & & & 0.19 \\
\hline Female & $525(56.0)$ & $410(55.0)$ & $76(39.8)$ & \\
\hline Male & $412(44.0)$ & $336(45.0)$ & $115(60.2)$ & \\
\hline Geographic region — no. (\%) & & & & 0.07 \\
\hline Northern Europe & $423(45.1)$ & $334(44.8)$ & $89(46.6)$ & \\
\hline United Kingdom & $277(29.6)$ & $218(29.2)$ & $59(30.9)$ & \\
\hline Australia and Hong Kong & $133(14.2)$ & $116(15.6)$ & $17(8.9)$ & \\
\hline Southern Europe & $56(6.0)$ & $46(6.2)$ & $10(5.2)$ & \\
\hline South Africa & $44(4.7)$ & $29(3.9)$ & $15(7.9)$ & \\
\hline Americas & $4(0.4)$ & $3(0.4)$ & $1(0.5)$ & \\
\hline Eligibility status — no. (\%) & & & & 0.63 \\
\hline Clinical diagnosis & $163(17.4)$ & $132(17.7)$ & $31(16.2)$ & \\
\hline Genetic diagnosis & $774(82.6)$ & $614(82.3)$ & $160(83.8)$ & \\
\hline Mutation - no./total no. (\%) & & & & 0.18 \\
\hline MLH1 & $464 / 774(60.0)$ & $358 / 614(58.3)$ & $106 / 160(66.3)$ & \\
\hline $\mathrm{MSH} 2$ & $284 / 774$ (36.7) & $235 / 614(38.3)$ & $49 / 160(30.6)$ & \\
\hline MSHG & $26 / 774(3.4)$ & $21 / 614(3.4)$ & $5 / 160(3.1)$ & \\
\hline \multicolumn{5}{|l|}{ Time in study - mo } \\
\hline Mean & & 29.0 & & \\
\hline Range & & $7-74$ & & \\
\hline \multicolumn{5}{|c|}{ Duration of receipt of study drug - mo } \\
\hline Mean & & 26.5 & & \\
\hline Range & & $1-67$ & & \\
\hline \multicolumn{5}{|c|}{ No. of colonoscopic examinations } \\
\hline Mean & & 2.6 & & \\
\hline Range & & $2-7$ & & \\
\hline
\end{tabular}

* The $\mathrm{P}$ values are for the comparisons of patients who were included in the analysis with the patients who were not included. 
justed for age and sex. Adjustment for the presence or absence of bowel neoplasms before participation in the study, the number of colonoscopic examinations, or both with the use of generalized linear models gave results that were equivalent to those seen after adjustment for age and sex only; these results are not reported. Time-to-event analysis was used in the secondary analysis, with the number of months to detection of any neoplasia or an advanced adenoma or colorectal cancer as end points. Cox proportional-hazards models adjusted for age and sex were used for treatment effects and KaplanMeier survival curves.

Pearson's chi-square test was used for analyses of reasons for withdrawal from the study and serious adverse events as defined in the trial (peptic ulcer, cerebrovascular incident, cardiovascular incident, deep venous thrombosis, cancer not associated with the Lynch syndrome, cancer other than colorectal cancer associated with the Lynch syndrome, other major events, and other minor events, including bleeding). Analyses included all events that occurred after study entry.

We anticipated that at least one adenoma would develop over a period of 2 years in $10 \%$ of the patients in the placebo group ${ }^{18}$; assuming a $20 \%$ dropout rate, we calculated that a sample of 1200 participants followed for 2 years would provide $90 \%$ power at a significance level of 0.05 , based on a treatment effect of a $40 \%$ reduction in risk. The study had $73 \%$ power to detect a $50 \%$ reduction in the risk of an advanced adenoma or carcinomas.

Since there were fewer eligible gene carriers than predicted, an early approved protocol amendment allowed participants to remain in the study longer; this reduced the target recruitment to 1000 persons, assuming that $20 \%$ of participants would withdraw from the study and that $20 \%$ would continue for 2 more years. This amendment also stated that all participants would be included in the analysis, provided that there was a colonoscopic examination at both study entry and study exit and regardless of the time in the study.

\section{RESULTS}

CHARACTERISTICS OF THE PATIENTS

We recruited 1009 eligible patients. The analysis excluded 263 participants (26\%); 72 withdrew before the colonoscopic examination at study entry, and 191 withdrew before the follow-up colonoscopic examination. The remaining 746 participants were included in the analysis. There were no notable differences between the patients who were recruited and those who completed the study.

Table 1 and Table 1 in the Supplementary Appendix (available with the full text of this article at www.nejm.org) show the characteristics of the participants; at recruitment, $83 \%$ had a genetic diagnosis, and $17 \%$ had a clinical diagnosis. Subsequently, a mismatch-repair mutation was discovered in 49 of 163 patients who had a clinical diagnosis, but the original status was retained for the analysis. A total of 464 participants with a genetic diagnosis had a pathologic mutation in MLH1, 284 had a mutation in MSH2, and 26 had a mutation in MSH6. A total of 152 Finnish participants had an MLH1 exon 16 deletion, and 35 South African participants had a C1528T MLH1 mutation. For at least $80 \%$ of the time, $81 \%$ of participants complied with the use of aspirin and $77 \%$ of the participants complied with the use of resistant starch. A subgroup of 100 participants from the United Kingdom completed a 4-day dietary assessment and provided a urine sample; the compliance biomarker 4-aminobenzoic acid was detected in $93 \%$ of these participants.

The average duration of participation in the study was 29 months (range, 7 to 74); they received the study drugs for 27 months (Table 1) and underwent an average of 3 colonoscopic examinations (range, 2 to 7, including the examination at study entry). There was even distribution among study groups (Table 2) with regard to total years of follow-up, the mean age of the participants, and the number of colonoscopic examinations. Table 2 includes data on participants who were randomly assigned to receive one agent only. A central histologic review of all of the available tumor tissue obtained from 132 of 197 persons $(67.0 \%)$ was performed. There was 93\% agreement between local and central reviews of detected neoplasia and $79 \%$ agreement for classification of nonadvanced and advanced neoplasia. Discordant opinions were reviewed by the study team, and the opinion of the reviewers at the central site was preferred if it was clear that both pathologists had examined the same tissue. 


\begin{tabular}{|c|c|c|c|c|c|}
\hline \multirow[t]{2}{*}{ Variable } & \multirow[t]{2}{*}{$\begin{array}{l}\text { All Participants } \\
\text { Recruited } \\
(\mathrm{N}=937)\end{array}$} & \multicolumn{4}{|c|}{ Participants Assigned to Both Interventions } \\
\hline & & $\begin{array}{l}\text { Aspirin plus } \\
\text { Resistant Starch } \\
(\mathrm{N}=214)\end{array}$ & $\begin{array}{l}\text { Aspirin plus } \\
\text { Placebo } \\
(\mathrm{N}=204)\end{array}$ & $\begin{array}{l}\text { Resistant Starch } \\
\text { plus Placebo } \\
(\mathrm{N}=208)\end{array}$ & $\begin{array}{l}\text { Placebo } \\
\text { plus Placebo } \\
(\mathrm{N}=216)\end{array}$ \\
\hline Withdrawal from study — no. (\%) & $191(20.4)$ & $39(18.2)$ & $38(18.6)$ & $51(24.5)$ & $40(18.5)$ \\
\hline Inclusion in analysis — no. (\%) & $746(79.6)$ & $175(81.8)$ & $166(81.4)$ & $157(75.5)$ & $176(81.5)$ \\
\hline \multicolumn{6}{|l|}{ Age $-y r$} \\
\hline Mean & & 44 & 43 & 43 & 44 \\
\hline Range & & $24-8$ & $21-68$ & $24-75$ & $25-77$ \\
\hline \multicolumn{6}{|l|}{ Sex - no./total no. (\%) } \\
\hline Female & $410 / 746(55.0)$ & $94 / 175(53.7)$ & $103 / 166(62.0)$ & $80 / 157(51.0)$ & $96 / 176(54.5)$ \\
\hline Male & $336 / 746(45.0)$ & $81 / 175(46.3)$ & $63 / 166(38.0)$ & $77 / 157(49.0)$ & $80 / 176(45.4)$ \\
\hline \multicolumn{6}{|l|}{ Diagnosis - no./total no. (\%) } \\
\hline Clinical & $132 / 746(17.7)$ & $21 / 175(12.0)$ & $29 / 166(17.5)$ & $33 / 157(21.0)$ & $31 / 176(17.6)$ \\
\hline Genetic & $614 / 746(82.3)$ & $154 / 175(88.0)$ & $137 / 166(82.5)$ & $124 / 157(79.0)$ & $145 / 176(82.4)$ \\
\hline \multicolumn{6}{|c|}{$\begin{array}{l}\text { Neoplasia before study entry — no./total no. } \\
\text { with full, available medical records (\%) }\end{array}$} \\
\hline No & $231 / 525(44.0)$ & $57 / 128(44.5)$ & $55 / 108(50.9)$ & $48 / 114(42.1)$ & $57 / 123(46.3)$ \\
\hline Yes & $294 / 525(56.0)$ & $71 / 128$ (55.5) & $53 / 109(49.1)$ & $66 / 114$ (57.9) & $66 / 123(53.7)$ \\
\hline \multicolumn{6}{|c|}{$\begin{array}{l}\text { Neoplasia at colonoscopic examination } \\
\text { at study entry — no./total no. (\%) }\end{array}$} \\
\hline No & $641 / 746(85.9)$ & $155 / 175(88.6)$ & $140 / 166(84.3)$ & $134 / 157(85.4)$ & $154 / 176(87.5)$ \\
\hline Yes & $105 / 746(14.1)$ & 20/175 (11.4) & $26 / 166(15.7)$ & $23 / 157(14.6)$ & $22 / 176(12.5)$ \\
\hline $\begin{array}{l}\text { Advanced adenoma at colonoscopic } \\
\text { examination at study entry - } \\
\text { no./total no. }(\%)\end{array}$ & $35 / 746(4.7)$ & $9 / 175(5.1)$ & $6 / 166(3.6)$ & $9 / 157(5.7)$ & $8 / 176(4.5)$ \\
\hline \multicolumn{6}{|l|}{ No. of adenomas - no./total no. (\%) } \\
\hline 1 & $88 / 105$ (83.8) & 16 & 23 & 18 & 18 \\
\hline 2 & $13 / 105(12.4)$ & 4 & 2 & 3 & 3 \\
\hline 3 & $3 / 105(2.9)$ & 0 & 0 & 2 & 1 \\
\hline 4 & $0 / 105$ & 0 & 0 & 0 & 0 \\
\hline 5 & $1 / 105(0.9)$ & 0 & 1 & 0 & 0 \\
\hline Total & $105 / 105(100)$ & 20 & 26 & 23 & 22 \\
\hline \multicolumn{6}{|l|}{ No. of colonoscopic examinations } \\
\hline Mean & & 2.6 & 2.6 & 2.7 & 2.7 \\
\hline Range & & $2-7$ & $2-6$ & $2-6$ & $2-5$ \\
\hline \multicolumn{6}{|l|}{ Follow-up $-y r$} \\
\hline Total person-years of follow-up & & 415 & 393 & 390 & 434 \\
\hline Mean & & 2.4 & 2.4 & 2.5 & 2.5 \\
\hline Range & & $0.8-4.7$ & $0.7-4.5$ & $0.9-6.2$ & $0.9-4.9$ \\
\hline \multicolumn{6}{|l|}{ Compliance } \\
\hline Mean proportion of unused aspir & tablets & 0.11 & 0.09 & 0.11 & 0.13 \\
\hline Mean proportion of unused starc & achets & 0.14 & 0.10 & 0.16 & 0.14 \\
\hline
\end{tabular}




\begin{tabular}{|c|c|c|c|}
\hline \multicolumn{4}{|c|}{ Participants Assigned to a Single Intervention } \\
\hline $\begin{array}{l}\text { Aspirin } \\
\text { Only } \\
(\mathrm{N}=9)\end{array}$ & $\begin{array}{l}\text { Placebo } \\
\text { Only } \\
(\mathrm{N}=10)\end{array}$ & $\begin{array}{c}\text { Resistant Starch } \\
\text { Only } \\
(\mathrm{N}=41)\end{array}$ & $\begin{array}{l}\text { Placebo } \\
\text { Only } \\
(\mathrm{N}=35)\end{array}$ \\
\hline 0 & 0 & $15(36.6)$ & $8(22.9)$ \\
\hline $9(100)$ & $10(100)$ & $26(63.4)$ & $27(77.1)$ \\
\hline 59 & 47 & 54 & 57 \\
\hline $36-71$ & $32-56$ & $27-78$ & $40-74$ \\
\hline $4 / 9(44.4)$ & $4 / 10(40.0)$ & $14 / 26(53.8)$ & $15 / 27(55.6)$ \\
\hline $5 / 9(55.6)$ & $6 / 10(60.0)$ & $12 / 26(46.1)$ & $12 / 27(44.4)$ \\
\hline $2 / 9(22.2)$ & $1 / 10(10.0)$ & $9 / 26(34.6)$ & $6 / 27(22.2)$ \\
\hline $7 / 9(77.8)$ & $9 / 10(90.0)$ & $17 / 26(65.4)$ & $21 / 27(77.8)$ \\
\hline $3 / 7$ (42.9) & $2 / 7(28.6)$ & $3 / 19(15.8)$ & $6 / 19(31.6)$ \\
\hline 4/7 (57.1) & $5 / 7$ (71.4) & $16 / 19$ (84.2) & $13 / 19(68.4)$ \\
\hline $7 / 9$ (77.8) & $8 / 10(80.0)$ & $21 / 26(80.8)$ & $22 / 27(81.5)$ \\
\hline $2 / 9(22.2)$ & $2 / 10(20.0)$ & $5 / 26(19.2)$ & $5 / 27(18.5)$ \\
\hline 0/9 & $0 / 10$ & $2 / 26(7.7)$ & $1 / 27(3.7)$ \\
\hline 2 & 2 & 4 & 5 \\
\hline 0 & 0 & 1 & 0 \\
\hline 0 & 0 & 0 & 0 \\
\hline 0 & 0 & 0 & 0 \\
\hline 0 & 0 & 0 & 0 \\
\hline 2 & 2 & 5 & 5 \\
\hline 2 & 2.7 & 2.7 & 2.8 \\
\hline $2-2$ & $2-5$ & $2-5$ & $2-5$ \\
\hline 17 & 27 & 63 & 65 \\
\hline 1.9 & 2.7 & 2.4 & 2.4 \\
\hline $1.6-2.1$ & $1.9-4.6$ & $0.6-4.3$ & $1.0-4.8$ \\
\hline - & - & - & - \\
\hline
\end{tabular}

\section{OUTCOMES}

A bowel neoplasm was identified in 141 participants $(18.9 \%)$, reflecting $90 \%$ power to detect a $40 \%$ difference in risk, as anticipated. Isolated colorectal cancer occurred in 13 participants, a combination of colorectal cancer and adenomas in 10, and adenomas only in the remaining 118. Numbers and mean diameters of the neoplasms are listed in Table 3. Table 4 shows the comparison for the two study agents separately; of 693 participants who were randomly assigned to receive aspirin or placebo, 66 of 349 (18.9\%) had one or more neoplastic lesions while receiving aspirin, as compared with 65 of 342 in the placebo group (19.0\%). Overall, the crude relative risk for the development of neoplasms in the aspirin group was 1.0 ( $95 \%$ confidence interval [CI], 0.7 to 1.4). After adjustment for age at enrollment, sex, and the number of colonoscopic examinations, there was no statistical evidence of a difference between the active-treatment and placebo groups. The analyses of adenomas only, colorectal cancer only, and adenomas and colorectal cancer showed no significant differences among the study groups. There was no evidence of an interaction between study agents $(\mathrm{P}=0.98)$.

The incidence of advanced adenoma or colorectal cancer, a measure of overt cancer plus adenomas thought to have the highest malignant potential, was $8.4 \%$ in the aspirin group and $10.9 \%$ in the placebo group $(\mathrm{P}=0.3)$. Of the 727 participants who were randomly assigned to receive resistant starch or placebo, 67 of those in the resistant-starch group (18.7\%) were found to have neoplasia, as compared with 68 in the placebo group (18.4\%), corresponding to a crude odds ratio of 1.0 ( $95 \%$ CI, 0.7 to 1.4). Adenomas and colorectal cancers were distributed evenly between the two groups (Table 4).

Colorectal cancer developed in equal numbers of patients (10) in the aspirin and placebo groups (Table 2 in the Supplementary Appendix). In the aspirin group, colorectal cancer with or without additional adenomas developed in 20 participants, 10 of whom were receiving active treatment and 10 of whom were receiving placebo. In the resistant-starch group, colorectal cancer with or without additional adenomas developed in 22 participants, 10 of whom were receiving active treatment and 12 of whom were receiving placebo. A Lynch syndrome cancer (excluding colorectal cancer) developed in 7 participants who re- 


\begin{tabular}{|c|c|c|c|c|c|c|c|c|c|}
\hline \multirow[t]{2}{*}{ Variable } & \multirow{2}{*}{$\begin{array}{l}\text { All Participants } \\
\text { No. (\%) }\end{array}$} & \multicolumn{4}{|c|}{ Participants Assigned to Both Interventions } & \multicolumn{4}{|c|}{$\begin{array}{l}\text { Participants Assigned to a Single } \\
\text { Intervention }\end{array}$} \\
\hline & & $\begin{array}{l}\text { Aspirin } \\
\text { plus } \\
\text { Resistant } \\
\text { Starch }\end{array}$ & $\begin{array}{l}\text { Aspirin } \\
\text { plus } \\
\text { Placebo }\end{array}$ & $\begin{array}{l}\text { Resistant } \\
\text { Starch } \\
\text { plus } \\
\text { Placebo }\end{array}$ & $\begin{array}{l}\text { Placebo } \\
\text { plus } \\
\text { Placebo }\end{array}$ & $\begin{array}{l}\text { Aspirin } \\
\text { Only }\end{array}$ & $\begin{array}{l}\text { Placebo } \\
\text { Only }\end{array}$ & $\begin{array}{c}\text { Resistant } \\
\text { Starch } \\
\text { Only }\end{array}$ & $\begin{array}{l}\text { Placebo } \\
\text { Only }\end{array}$ \\
\hline No neoplasia — no./total no. (\%) & $605 / 746(81.1)$ & 142 & 137 & 127 & 143 & 5 & 8 & 22 & 21 \\
\hline Neoplasia — no./total no. (\%) & $141 / 746(18.9)$ & 33 & 29 & 30 & 33 & 4 & 2 & 4 & 6 \\
\hline Adenoma only & $118 / 746(15.8)$ & 29 & 24 & 24 & 29 & 3 & 2 & 4 & 3 \\
\hline Colorectal cancer only & $13 / 746(1.7)$ & 2 & 2 & 4 & 3 & 1 & 0 & 0 & 1 \\
\hline Adenoma and colorectal cancer & $10 / 746(1.3)$ & 2 & 3 & 2 & 1 & 0 & 0 & 0 & 2 \\
\hline $\begin{array}{l}\text { Advanced adenoma or colo- } \\
\text { rectal cancer }\end{array}$ & $68 / 746(9.1)$ & 10 & 15 & 18 & 15 & 1 & 1 & 3 & 5 \\
\hline \multicolumn{10}{|l|}{ Largest dimension of neoplasm $-\mathrm{mm}$} \\
\hline Mean & 137 & 8.0 & 10.3 & 10.8 & 8.3 & 2.9 & 8 & 11.5 & 13.0 \\
\hline Range & & $1-68$ & $2-39$ & $1-70$ & $1-40$ & $1-5$ & $8-8$ & $3-23$ & $2-55$ \\
\hline \multicolumn{10}{|l|}{ No. of adenomas - no/total no. (\%) } \\
\hline 1 & $97 / 128(75.8)$ & 24 & 21 & 19 & 23 & 3 & 1 & 3 & 3 \\
\hline 2 & $20 / 128(15.6)$ & 5 & 4 & 3 & 5 & 0 & 1 & 0 & 2 \\
\hline 3 & $6 / 128(4.7)$ & 1 & 1 & 3 & 1 & 0 & 0 & 0 & 0 \\
\hline 4 & $2 / 128(1.6)$ & 1 & 0 & 0 & 1 & 0 & 0 & 0 & 0 \\
\hline 5 & $3 / 128(2.3)$ & 0 & 1 & 1 & 0 & 0 & 0 & 1 & 0 \\
\hline Total & $128 / 128(100)$ & 31 & 27 & 26 & 30 & 3 & 2 & 4 & 5 \\
\hline
\end{tabular}

ceived resistant starch, as compared with 17 who received placebo $(\mathrm{P}=0.05)$.

To test the influence of treatment duration on outcomes, ${ }^{19}$ we examined the incidence of neoplasia according to the number of years in the study. Hazard ratios (and 95\% confidence intervals) for all bowel neoplasms and advanced neoplasms revealed no evidence of a greater benefit with a longer duration of treatment (Fig. 1A through 1D). The analysis of all pathology reports in each of four 12-month periods, commencing at 6 months, showed no trend for a benefit of resistant starch over time but showed a possible adverse trend for aspirin, with the relative risk of neoplasia increasing from 0.6 to 1.9. Small numbers meant that for each group the confidence interval included 1 (Table 5 in the Supplementary Appendix).

\section{ADVERSE EVENTS}

Table 3 in the Supplementary Appendix lists reasons for withdrawal from the study. Serious adverse events (Table 4 in the Supplementary Appendix) were infrequent and did not differ significantly between groups. A total of 11 patients who received aspirin had gastric ulcers or bleeding versus 9 patients receiving placebo, 2 receiving aspirin had cerebrovascular events versus 3 receiving placebo, and 1 receiving aspirin had a cardiovascular event versus 5 among those receiving placebo.

DISCUSSION

We found that neither aspirin (at a dose of 600 mg per day) nor resistant starch (Novelose) (at a dose of $30 \mathrm{~g}$ per day), alone or in combination, given for up to 4 years has any detectable effect on the incidence of intestinal neoplasms among adults with the Lynch syndrome. Furthermore, the $40 \%$ reduction in neoplasms postulated for aspirin lies at the extreme limit of possible effects, as evidenced by the confidence interval. The lack of effect of aspirin, despite evidence of a 


\begin{tabular}{|c|c|c|c|c|c|c|}
\hline Variable & $\begin{array}{l}\text { Aspirin } \\
(N=350)\end{array}$ & $\begin{array}{l}\text { Placebo } \\
(\mathrm{N}=343)\end{array}$ & P Value & $\begin{array}{l}\text { Resistant Starch } \\
\qquad(\mathrm{N}=358)\end{array}$ & $\begin{array}{l}\text { Placebo } \\
(\mathrm{N}=369)\end{array}$ & $P$ Value \\
\hline \multicolumn{7}{|l|}{ Development of neoplasia — no. of patients (\%) } \\
\hline No neoplasia & 284 & 278 & & 291 & 301 & \\
\hline Neoplasia & $66(18.9)$ & $65(19.0)$ & 0.96 & $67(18.7)$ & $68(18.4)$ & 0.99 \\
\hline Adenoma only & $56(16.0)$ & $55(16.0)$ & 0.96 & $57(15.9)$ & $56(15.2)$ & 0.86 \\
\hline Colorectal cancer only & $5(1.4)$ & $7(2.0)$ & 0.54 & $6(1.7)$ & $6(1.6)$ & 0.90 \\
\hline Adenoma and colorectal cancer & $5(1.4)$ & $3(0.9)$ & 0.45 & $4(1.1)$ & $6(1.6)$ & 0.43 \\
\hline Advanced adenoma or colorectal cancer & $26(7.4)$ & $34(9.9)$ & 0.33 & $31(8.7)$ & $35(9.5)$ & 0.61 \\
\hline \multicolumn{7}{|l|}{ Neoplastic burden $-\mathrm{mm} \uparrow$} \\
\hline Mean & 8.7 & 9.4 & 0.7 & 9.4 & 9.5 & $1.0+$ \\
\hline Range & $0.4-68$ & $1-70$ & & $1-70$ & $1-55$ & \\
\hline \multicolumn{7}{|l|}{ No. of adenomas - no. of patients (\%) } \\
\hline 1 & $48(13.7)$ & $43(12.5)$ & & $46(12.8)$ & $47(12.7)$ & \\
\hline 2 & $9(2.6)$ & $9(2.6)$ & & $8(2.2)$ & $11(3.0)$ & \\
\hline 3 & $2(0.6)$ & $4(1.2)$ & & $4(1.1)$ & $2(0.5)$ & \\
\hline 4 & $1(0.3)$ & $1(0.3)$ & & $1(0.3)$ & $1(0.3)$ & \\
\hline 5 & $1(0.3)$ & $1(0.3)$ & & $2(0.6)$ & $1(0.3)$ & \\
\hline
\end{tabular}

* P values were adjusted for age and sex.

$\uparrow$ The neoplastic burden was estimated as the sum of the maximum diameters of lesions.

$\checkmark$ The $P$ value was calculated on the basis of the two-sided t-test.

benefit in sporadic colorectal cancer, ${ }^{1-3}$ may indicate a distinct mismatch-repair-dependent neoplastic pathway that is less susceptible to protection by aspirin. An analysis of expression of cyclooxygenase-2 by Lynch syndrome tumors is under way to test the reported association with aspirin as a chemopreventive agent. ${ }^{20}$ In our trial, aspirin was administered at a dose of $600 \mathrm{mg}$ daily. Baron et al. ${ }^{2}$ suggested that a daily dose of $325 \mathrm{mg}$ of aspirin is less effective than a daily dose of $81 \mathrm{mg}$, although epidemiologic studies provide support for a positive dose-response relationship.

The lack of an effect suggests that a larger study is unlikely to result in a different conclusion; more modest protective effects than the postulated $40 \%$ reduction in neoplasms are still consistent with our data but would require much larger samples to detect. The results of analyses restricted to proven mutation carriers were indistinguishable from the results presented here (data not shown). Polyps that were present but not detected at study entry could have weakened any effect, but a miss rate equivalent to that reported by Pickhardt et al. ${ }^{21}$ would not have changed the results. Furthermore, the frequency of such omissions would probably have been similar among the study groups.

The U.S. Preventive Services Task Force ${ }^{22}$ recommended that aspirin not be used routinely for the prevention of primary colorectal cancer. Subsequently, Flossmann and Rothwell ${ }^{19}$ reported longer-term effects of aspirin on the risk of death from cancer among British men in two early trials of the benefits of aspirin in cardiovascular and cerebrovascular disease. There were significantly fewer deaths from colorectal cancer among persons who received aspirin; however, this did not become apparent until 10 years after the trial commenced, even though the aspirin was given for only 4 years during the trial. Such an effect - through a later influence on the development of adenomas, the precursors of colorectal cancer - cannot be ruled out in the CAPP2 


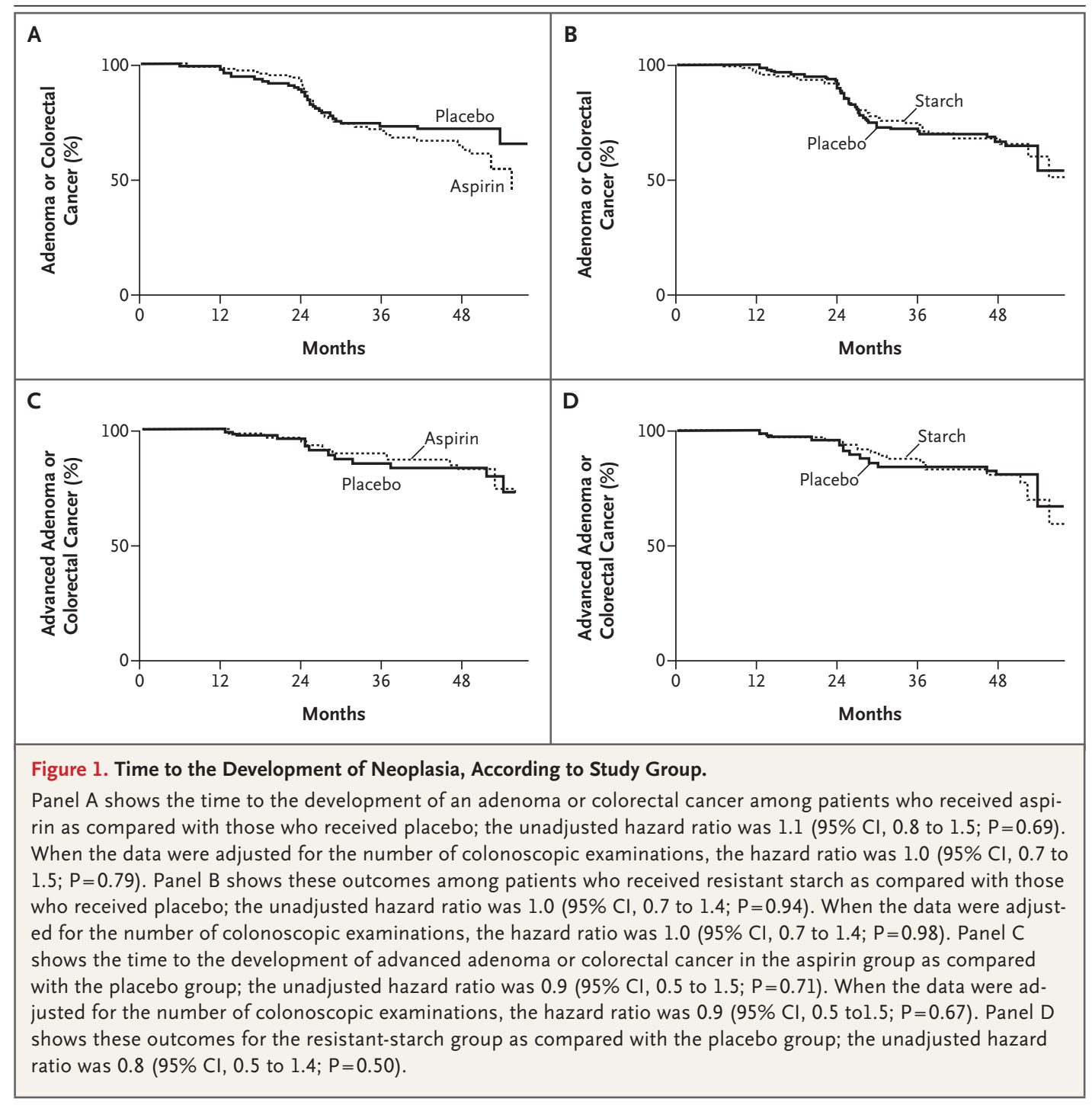

cohort and is supported by the reduced incidence of cancer among carriers of the Lynch syndrome gene who undergo removal of polyps at regular colonoscopic examinations. ${ }^{19}$

The limited preliminary evidence concerning resistant starch is insufficient to define the optimum dose, and the dose used in our study was based on earlier studies of biomarkers ${ }^{18}$ and tolerability. The dose we used was tolerable, but it was three times as high as the typical intake of resistant starch in Europe. The lack of effect may reflect an insufficient dose, a less-thanideal compliance rate $(77 \%)$, or the fact that a benefit in laboratory animals does not always translate into a benefit for humans.

Our trial has shown the feasibility of performing chemoprevention trials in a population of people with a genetic susceptibility. The results, however, do not show a clinical benefit among carriers of a mutation for the Lynch syndrome who receive aspirin or resistant starch for up to 4 years. Longer-term effects remain to be evaluated. 
Supported by Bayer, National Starch and Chemical, and grants from the U.K. Medical Research Council (G0100496), Cancer Research U.K. (C1297/A5013 and C588/A4994), the European Union (PL96/3694), the Cancer Council Victoria (Australia), The Technology and Human Resources for Industry ProgrammeSouth Africa, and the Finnish Cancer Foundation.

No potential conflict of interest relevant to this article was reported.
We thank the participants in the CAPP2 study who agreed to undergo randomization and receive daily study agents for up to 4 years; Kirsi Pylvänäinen (Jyvaskyla, Finland), Pascale Ives (Melbourne, Australia), and Su Werner (Dusseldorf, Germany), our leading recruiters; and Pam Chapman, the project manager in its early stages.

\section{APPENDIX}

The authors' affiliations are as follows: Institute of Human Genetics (J.B., G.B.) and Human Nutrition Research Centre, Newcastle University (J.C.M.), Newcastle upon Tyne; Leeds Institute of Molecular Medicine, Leeds University, Leeds (D.T.B., F.E.); Princess Anne Hospital, Southampton (D.E.); Medical and Molecular Genetics, University of Birmingham, Birmingham (E.R.M.); St. Mary's Hospital, Manchester (D.G.E.); Belfast City Hospital, Belfast (P.J.M.); Churchill Hospital, Oxford (L.S.); St. Mark's Hospital, Harrow, London (H.J.W.T., J.R.J.); and Western General Hospital, Edinburgh (M.D.) - all in the United Kingdom; Jyväskylä Central Hospital, Jyväskylä, Finland (J.-P.M.); Royal Melbourne Hospital, Melbourne (F.M.); and John Hunter Hospital, New Lambton (R.J.S.) - both in Australia; St. Josefs-Hospital, Bochum-Linden, Germany (G.M.); Institut Paoli-Calmettes, Marseille, France (S.O.); University of Copenhagen, Danish Hereditary Non-Polyposis Colon Cancer Register, Hvidovre, Denmark (M.-L.B.); University of Cape Town, Observatory, South Africa (R.R.); Istituto Nazionale per lo Studio e la Cura dei Tumori, Milan (L.B.); Helsinki University Central Hospital, Helsinki (H.J.J.); Karolinska Institutet, Stockholm (A.L.); International Hereditary Cancer Center, Szczecin, Poland (J.L.); Queen Mary Hospital, Hong Kong (J.W.C.H.); Leiden University Medical Center, Leiden (H.F.A.V.); and Erasmus University Medical Center, Rotterdam (R.F.) — both in the Netherlands; and Creighton University Medical Center, Omaha, NE (H.T.L.).

The study collaborators were as follows: P. Adamson, O. Armstrong, J. Ball, L. Baxter, A. Birkett, A. Boussioutas, N. Bradshaw, C. Brewer, M. Broughton, B. Bulman, M. Castiglione, S. Clarke, R. Ching, C. Chu, J. Coaker, S. Cina, J. Cook, J. Coxhead, G. Crawford, C. Cummings, R. Davies, T. Debniak, C. de Moncuit, S. Drummond, T. Ellis, K. Farthing, P. Fidalgo, S. Gallinger, J. Gascoyne, J. Gilroy, S. Goff, P. Goldberg, S. Goodman, C. Harocopos, S. Hodgson, R. Jeffcoat, L. Jeffers, S. Jordan, P. Killick, C. Krauss, J. Kristensen, C. Langman, J. Leite, A. Liljegren, G. Lindgren, L. Lynagh, C. Oliani, C. Marks, J. Miller, T. Miles, V. Murday, P. Perez Segura, E. Pietersen, U. Platten, L. Reed, G. Rossi, P. Sala, J. Sampson, B. Schmocker, J. Shaw, A. Spigelman, A. Tempesta, R. Toes, M. Velthuizen, P. Wakelen, I. Walpole; CAPP2 International Steering Committee - H. Lynch (chair), J. Burn, J. Mathers, D.T. Bishop, R. Fodde, J.-P. Mecklin, F. Macrae, H. Vasen, G. Möslein, R. Ramesar; Medical Research Council Trial Steering Committee - D. Kerr (chair), S. Perkins, J. Cuzick, L. Faulds Wood, R. Steele; Data and Safety Monitoring Committee - D. Altman (chair), C. Paraskeva, W. Atkin, M. Hull.

\section{REFERENCES}

1. Sandler RS, Halabi S, Baron JA, et al. A randomized trial of aspirin to preven colorectal adenomas in patients with previous colorectal cancer. N Engl J Med 2003;348:883-90. [Erratum, N Engl J Med 2003;348:1939.]

2. Baron JA, Cole B, Sandler RS, et al. A randomized trial of aspirin to prevent colorectal adenomas. N Engl J Med 2003; 348:891-9.

3. Benamouzig R, Deyra J, Martin A, et al. Daily soluble aspirin and prevention of colorectal adenoma recurrence: one-year results of the APACC trial. Gastroenterology 2003;125:328-36.

4. Logan RFA, Grainge MJ, Shepherd VC, Armitage NC, Muir KR. Aspirin and folic acid for the prevention of recurrent colorectal adenomas. Gastroenterology 2008; 134:29-38.

5. Schatzkin A, Lanza E, Corle D, et al. Lack of effect of a low-fat, high-fiber diet on the recurrence of colorectal adenomas. N Engl J Med 2000;342:1149-55.

6. Cassidy A, Bingham SA, Cummings JH. Starch intake and colorectal cancer risk: an international comparison. $\mathrm{Br} \mathrm{J}$ Cancer 1994;69:937-42.
7. Williams EA, Coxhead JM, Mathers JC. Anti-cancer effects of butyrate: use of micro-array technology to investigate mechanisms. Proc Nutr Soc 2003;62:10715.

8. Bauer-Marinovic M, Florian S, MüllerSchmehl K, Glatt H, Jacobasch G. Dietary resistant starch type 3 prevents tumor induction by 1,2-dimethylhydrazine and alters proliferation, apoptosis and dedifferentiation in rat colon. Carcinogenesis 2006;27:1849-59.

9. Le Leu RK, Brown IL, Hu Y, Morita T, Esterman A, Young GP. Effect of dietary resistant starch and protein on colonic fermentation and intestinal tumourigenesis in rats. Carcinogenesis 2007;28:240-5. 10. Perrin P, Pierre F, Patry Y, et al. Only fibres promoting a stable butyrate producing colonic ecosystem decrease the rate of aberrant crypt foci in rats. Gut 2001;48:53-61.

11. Toden S, Bird A, Topping D, Conlon M. Resistant starch prevents colonic DNA damage induced by high dietary cooked red mean or casein in rats. Cancer Biol Ther 2006;5:267-72.

12. Le Leu RK, Brown IL, Hu Y, Young GP.
Effect of resistant starch on genotoxininduced apoptosis, colonic epithelium, and lumenal contents in rats. Carcinogenesis 2003;24:1347-52.

13. Williamson SLH, Kartheuser A, Coaker J, et al. Intestinal tumorigenesis in the Apc1638N mouse treated with aspirin and resistant starch for up to 5 months. Carcinogenesis 1999;20:805-10.

14. Vasen HFA, Moslein G, Alonso A, et al. Guidelines for the clinical management of Lynch syndrome (hereditary non-polyposis cancer). J Med Genet 2007;44:35362.

15. Goel A, Arnold CN, Niedzwiecki D, et al. Characterization of sporadic colon cancer by patterns of genomic instability. Cancer Res 2003;63:1608-14.

16. De Jong AE, Morreau H, Van Puijenbroek $\mathrm{M}$, et al. The role of mismatch repair gene defects in the development of adenomas in patients with HNPCC. Gastroenterology 2004;126:42-8.

17. Asp N-G, van Amelsvoort JMM, Hautvast JGAJ. Nutritional implications of resistant starch. Nutr Res Rev 1996;9: 1-31.

18. Järvinen $\mathrm{HJ}$, Aarnio $\mathrm{M}$, Mustonen $\mathrm{H}$, 
et al. Controlled 15-year trial on screening for colorectal cancer in families with hereditary nonpolyposis colorectal cancer. Gastroenterology 2000;118:829-34.

19. Flossmann E, Rothwell PM. Effect of aspirin on long-term risk of colorectal cancer: consistent evidence from randomised and observational studies. Lancet 2007;369:1603-13.
20. Chan AT, Ogino S, Fuchs CS. Aspirin and the risk of colorectal cancer in relation to the expression of COX-2. N Engl J Med 2007;356:2131-42.

21. Pickhardt PJ, Choi JR, Hwang I, et al. Computed tomographic virtual colonoscopy to screen for colorectal neoplasia in asymptomatic adults. N Engl J Med 2003; 349:2191-200.
22. Routine aspirin or nonsteroidal antiinflammatory drugs for the primary prevention of colorectal cancer: U.S. Preventive Services Task Force recommendation statement. Ann Intern Med 2007;146:361-4. Copyright (c) 2008 Massachusetts Medical Society. 


\section{CORRECTION}

Effect of Aspirin or Resistant Starch on Colorectal Neoplasia in the Lynch Syndrome (December 11, 2008;359:2567-78). In Table 2 (pages 2572-2573), the third variable should be "Age at recruitment - yr," and the age ranges should read as follows: Aspirin plus Resistant Starch, 25-70; Aspirin plus Placebo, 25-75; Resistant Starch plus Placebo, 25-75; Placebo plus Placebo, 25-78; Aspirin Only, 37-67; Placebo Only, 33-57; Resistant Starch Only, 28-78; and Placebo Only, 36-75. In the first paragraph under Outcomes (page 2573), the data given in the fourth sentence should read, "66 of 350 (18.9\%) had one or more neoplastic lesions while receiving aspirin, as compared with 65 of 343 in the placebo group (19.0\%)." The article has been corrected at NEJM.org.

\section{NOTICES}

Notices submitted for publication should contain a mailing address and telephone number of a contact person or department. We regret that we are unable to publish all notices received. Notices also appear on the Journal's Web site (NEJM.org/meetings). The listings can be viewed in their entirety or searched by location, month, or key word.

\section{HISTORY OF SCIENCE AND MEDICINE}

A researcher working on a history of American graduate medical education is seeking diaries, journals, or correspondence written by physicians during their internships and/or residencies about their experiences in U.S. training programs between 1945 and 2003.

Contact Heather Varughese, Program in the History of Science and Medicine, Yale University, 333 Cedar Street, Room L 132, New Haven, CT 06520-8015; or call (203) 785-4338; or e-mail heather.varughese@yale.edu.

\section{CALL FOR APPLICATIONS}

The Health and Aging Policy Fellows Program is accepting applications for two fellowships, which support involvement in health policy at the federal, state, or local level. Deadline for submission is April 15.

Contact Dr. Pincus, Columbia University College of Physicians \& Surgeons, 1051 Riverside Dr., Unit 9, New York, NY 10032; or call (212) 543-5400; or e-mail pincush@pi.cpmc. columbia.edu; or see http://www.healthandagingpolicy.org.

\section{EMERGENCY MEDICINE (ZUSATZBEZEICHNUNG NOTFALLMEDIZIN)}

The course will be offered in Essen, Germany, Sept. 19-26.

Contact Dr. Frank Herbstreit, Dept. of Anesthesiology and Intensive Care Medicine, Faculty of Medicine, University Duisburg-Essen, Hufelandstrasse 55, 45122 Essen, Germany; or call (49) 201 723-1401; or fax (49) 201 723-5949; or e-mail frank.herbstreit@uk-essen.de.

\section{TH INTERNATIONAL SURGICAL PATHOLOGY SYMPOSIUM}

The symposium will be held in Berlin, May 5-8.

Contact Connie Levell, Mayo Medical Laboratories, $3050 \mathrm{Su}-$ perior Dr., NW, Rochester, MN 55905; or call (507) 538-6253 or (800) 533-1710; or fax (507) 284-8016; or see http://www. mayomedicallaboratories.com/education/surgpath2009.

\section{MAYO CLINIC SCOTTSDALE}

The following courses will be offered in Scottsdale, AZ, unless otherwise indicated: "A Multidisciplinary Update in Pulmonary \& Critical Care Medicine" (April 23-26) and "Health and Wellness Enhanced by Fitness and Sports" (Bradenton, FL, April 30-May 2).

Contact Mayo School of CME, Mayo Clinic, 13400 E. Shea Blvd., Scottsdale, AZ 85259; or call (480) 301-4580; or fax (480) 301-8323.

\section{AMERICAN SOCIETY OF TROPICAL MEDICINE AND HYGIENE}

The "58th Annual Meeting" will be held in Washington, DC, Nov. 18-22. Deadline for submission of abstracts and young investigator award applications is May 6.

Contact the American Society of Tropical Medicine and Hygiene, 111 Deer Lake Rd., Suite 100, Deerfield, IL 60015; or call (847) 480-9592; or fax (847) 480-9282; or e-mail info@astmh. org; or see http://www.astmh.org.

\section{CARDIOVASCULAR REVIEW AND UPDATE FOR THE PRACTITIONER}

The course will be offered in Boston, May 3-7. It is sponsored by Harvard Medical School, in cooperation with Brigham and Women's Hospital.

Contact Enola Mosley, Dept. of Continuing Education, Harvard Medical School, 401 Park Dr., 21 Landmark Center, 2nd Floor W., Boston, MA 02215; or call (617) 384-8606; or fax (617) 384-8686; or e-mail enola_mosley@hms.harvard.edu.

\section{UNIVERSITY OF MINNESOTA}

The following courses will be offered in Minneapolis, unless otherwise indicated: "Lillehei Symposium: Cardiovascular Care for Primary Practitioners" (April 20 and 21); "Family Medicine Update" (May 13-15); "Pediatric Dermatology" (May 15); "Bariatric Education Day" (May 21); "Workshops in Clinical Hypnosis" (Plymouth, MN, June 4-6); "Topics and Advances in Pediatrics" (June 4 and 5); and "Advances in Gastrointestinal and GI Laparoscopic Surgery 2009” (June 10-13).

Contact the Office of CME, University of Minnesota, University Park Plaza, Suite 601, 2829 University Ave. SE, Minneapolis, MN 55414; or call (612) 626-7600; or fax (612) 626-7766; or e-mail cme@umn.edu; or see http://www.cme.umn.edu.

\section{NORTH CAROLINA OCCUPATIONAL SAFETY} AND HEALTH EDUCATION AND RESEARCH CENTER

The following courses will be offered in Chapel Hill, NC: "Certified Safety Professional (CSP) Review Course" (April 20-24); "Certified Hazardous Material Manager (CHMM) Review" (May 4-7); "COHN/Safety Management Certification Review Course" (June 8-11); and "Supervising Asbestos Abatement Projects" (June 22-26).

Contact the Occupational Safety and Health Education and Research Center, University of North Carolina, P.O. Box 16248, Chapel Hill, NC 27516-6248; or call (888) 235-3320 or (919) 962-2101; or fax (919) 966-7579; or e-mail osherc@unc.edu; or see http://www.osherc.sph.unc.edu.

\section{COMPUTER ASSISTED RADIOLOGY AND SURGERY}

The "23rd International Congress and Exhibition" will be held in Berlin, June 23-27.

Contact the CARS Conference Office, Im Gut 15, 79790 Kuessaberg, Germany; or call (49) 7742-922 434; or fax (49) 7742-922 438; or e-mail office@cars-int.org; or see http://www.cars-int.org.

\section{COAGULATION TESTING QUALITY}

The conference and workshop will be held in Minneapolis, April 14-17.

Contact Mayo Medical Laboratories, 3050 Superior Dr., NW, Rochester, MN 55901; or call (507) 284-0286; or fax (507) 2848016; or e-mail strain.diane@mayo.edu; or see http://www. mayomedicallaboratories.com/education/coag2009. 